\title{
Effects of sowing dates and irrigation regimes on grain quality of wheat grown under semi-arid condition of India
}

\author{
Rajesh Kumar Meena ${ }^{1 *}$, S.S. Parihar ${ }^{2}$, Man Singh ${ }^{3}$ and Manoj Khanna ${ }^{4}$ \\ ${ }^{1}$ ICAR-National Bureau of Soil Survey and Land Use Planning, Regional Centre, Indian Agricultural Research \\ Institute (IARI) Campus, New Delhi-110012, INDIA \\ ${ }^{2,3,4}$ Water Technology Centre, ICAR-IARI, New Delhi-110 012, INDIA \\ *Corresponding author. E-mail: rkmwtc@gmail.com
}

Received: July 29, 2015; Revised received: April 5, 2016; Accepted: June 3, 2016

\begin{abstract}
An experiment was conducted with aim to investigate the effect of sowing dates and irrigation regimes on wheat grain quality. There was four sowing dates [November $1\left(S_{1}\right)$, November $16\left(S_{2}\right)$, December $1\left(S_{3}\right)$ and December $16\left(S_{4}\right)$ ], in main plots and four irrigation regimes $\left[25 \%\left(I_{1}\right), 50 \%\left(I_{2}\right)\right.$ and $75 \%\left(I_{3}\right)$ maximum allowable depletion (MAD) of available soil moisture (ASM) and $\mathrm{I}_{4}-$ four critical growth stages in sub plots. The results revealed that hectolitre weight decreased from 80.2 and $81.4 \mathrm{~kg} \mathrm{hl}^{-1}$ in $\mathrm{S}_{1}$ treatment to 78.3 and $79.4 \mathrm{~kg} \mathrm{hl}^{-1}$ in $\mathrm{S}_{4}$ treatment and 79.9 and $81.5 \mathrm{~kg} \mathrm{hl}^{-1}$ in $\mathrm{I}_{1}$ treatment to 79.0 and $79.9 \mathrm{~kg} \mathrm{hl}^{-1}$ in $\mathrm{I}_{3}$ treatment in 2010-11 and 2011-12, respectively. Grain hardness outcome was $\geq 75$ in 2010-11 while it was $<75$ in 2011-12 irrespective of sowing dates and irrigation regimes. The highest percentage of flour recovery obtained in $S_{1}$ treatment $(68.2$ and $63.2 \%)$ and $I_{1}$ treatment $(68.0$ and $62.8 \%$ ) with lowest coarse bran. On average, dry gluten content increased by 16.5 and $7.1 \%$ in $S_{4}$ over $S_{1}$ treatment in 2010-11 and 2011-12, respectively. Grain protein content increased from 11.9 and $12.8 \%$ in $S_{1}$ treatment to 12.6 and $13.8 \%$ in $S_{4}$ treatment in respective seasons. The milling and technological properties in $S_{2}$ and $I_{2}$ treatment was at par with $S_{1}$ and $I_{2}$ treatment. Therefore, it may be inferred that optimum milling and technological properties of wheat grain can be maintained by sowing till mid-November and irrigation scheduling up to $50 \%$ depletion of ASM.
\end{abstract}

Keywords: Irrigation regime, Maximum allowable depletion, Sowing date, Wheat quality

\section{INTRODUCTION}

Bread wheat (Triticum aestivum L.) is one of the most important staple food crops and reportedly contributes $28 \%$ of the world edible dry matter and provides up to $60 \%$ of daily calorie uptake in developing country and leading source of vegetable protein among cereals in human food (Singh et al., 2010 and 2012). As much of wheat production consumed by human, the quality of wheat grain flour has marked effects on human nutrition and health. In India, $75 \%$ of wheat production is milled into flour to make chapati/roti (unleavened flat bread). With changing consumption pattern as a result of urbanization, increased purchasing powers, substitution to other cereals and awareness of consumers, the demand for wheat based value added products is expected to rise further in near future. The quality requirement for wheat based products are different, hence, industry may also demand more product specific quality. With increasing market opportunities and entry of private sector in wheat industry, the demand for stable grain quality would increase in future (Coventry et al., $2011 \mathrm{a}, \mathrm{b}$ ).

In semi-arid region of India, wheat grown on light textured soil frequently exposed to both moisture and high temperature stress during wheat growing season particu- larly at grain filling stage. The frequent exposure of crop to more than one extreme event in a single growing season influences crop yield and grain quality. The frequency of weather events and extremes likely to increase in future and thereby influence better grain quality, which going to be determinant of wheat grain price. Hence, farmers need a package of agronomic practices that ensure better grain quality in uncertain growing conditions. Amongst agronomic practices, the sowing time and irrigation plays an important role in influencing the quality of wheat grain. Ideal soil, water and climatic condition, prevailing in optimum sowing is responsible for quality of bread wheat with good hectolitre weight but grain protein content, dry gluten content and sedimentation index were obtained higher in late sown wheat (Zende et al., 2005). By agronomic interventions such as proper sowing time and irrigation schedule ensure stable grain quality. Therefore, this paper seeks to clarify the effect of different sowing dates and irrigation regimes on wheat grain quality under semi arid condition of India.

\section{MATERIALS AND METHODS}

Experimental site, soil and climate: The study area was located at the experimental farm of Water 
Technology Centre, Indian Agricultural Research Institute (IARI), New Delhi ( $28^{\circ} 38^{\prime} 56.2^{\prime \prime}$ N, $77^{\circ} 11^{\prime} 37.6^{\prime \prime}$ E; $228.7 \mathrm{~m}$ above mean sea level), India. The field experiment was conducted for 2 consecutive rabi season of 2010-11 (Year I) and 2011-12 (Year II).

The soil of the study area is sandy loam (Typic Haplustepts) in texture with medium angular blocky structure and non-calcareous in nature. Chemically, soil is of neutral $\mathrm{pH}$; low in organic carbon and available $\mathrm{N}$; medium in available (Olsen) $\mathrm{P}$ and available $\mathrm{K}$ in $0-30 \mathrm{~cm}$ soil depth. The soil physical properties $(0-$ $30 \mathrm{~cm}$ ) are bulk density: $1.52 \mathrm{Mg} \mathrm{m}^{-2}$; saturated hydraulic conductivity: $1.09 \mathrm{~cm} \mathrm{~h}^{-1}$ and sand, silt and clay, 70.9, 12.8 and 16.9, respectively. Available soil moisture ranges from $17.2 \%$ (field capacity) to $7.5 \%$ (wilting point) in 0 to $0.90 \mathrm{~m}$ layers.

The region is characterized by a semi-arid and subtropical climate with hot dry summer (March-June), wet monsoon season (late June-mid September) and cold winter seasons (November-February) and falls under the agro-climatic zone of "Trans-Gangetic plains". The mean annual rainfall is $734 \mathrm{~mm}$, of which approx. $80 \%$ falls during active south-west monsoon months from July to September.

Experimental design and treatments: The experimental design was a split-plot with replicated thrice. There were sixteen treatments, involving four sowing dates namely, $\mathrm{S}_{1}$ - November $1 ; \mathrm{S}_{2}$ - November $16 ; \mathrm{S}_{3}$ December 1; $\mathrm{S}_{4}$ - December 16, in main plots and four irrigation regimes were, $\mathrm{I}_{1}-25 \%$ maximum allowable depletion (MAD) of available soil moisture (ASM), $\mathrm{I}_{2}$ - $50 \%$ MAD of ASM, $\mathrm{I}_{3}-75 \%$ MAD of ASM, $\mathrm{I}_{4}-$ based on four (crown root initiation, late jointing, flowering and milking) critical growth stages, in subplots.

Crop cultivar, irrigation scheduling and agronomic practices: Wheat cultivar DBW-17, a semi-dwarf variety with 135-145 days cropping duration, was used for sowing. Wheat seeds were sown in rows $20 \mathrm{~cm}$ apart as per treatment schedule with seed rate @100 kg ha ${ }^{-1}$ $\left(\mathrm{S}_{1}\right.$ and $\left.\mathrm{S}_{2}\right)$ and $110 \mathrm{~kg} \mathrm{ha}^{-1}\left(\mathrm{~S}_{3}\right.$ and $\left.\mathrm{S}_{4}\right)$ to maintain optimum plant population. The row orientation was northsouth to facilitate favourable micro-climate. The plots dimensions were $5 \times 4 \mathrm{~m}$. The crop applied N@120 $\mathrm{kg} \mathrm{ha}^{-1}$ with half dose of $\mathrm{N}\left(60 \mathrm{~kg} \mathrm{ha}^{-1}\right)$ and full dose of $\mathrm{P}\left(60 \mathrm{~kg} \mathrm{ha}^{-1}\right)$ and $\mathrm{K}\left(40 \mathrm{~kg} \mathrm{ha}^{-1}\right)$ as basal and remaining $\mathrm{N}$ was applied in 2 equal doses, half at first and the rest half at second irrigation. The source of N, P, and K were urea, Diammonium phosphate (DAP) and murate of potash (MOP), respectively. Pre-emergence application of chloropyriphos (or confidor) and pendimethalin were given on same day after sowing followed by one weeding cum hoeing was done at 40 DAS and chloropyriphos (or confidor) applied whenever termite infestation appeared in the plots. The irrigation scheduling was done on the basis of soil moisture depletion in the root zone determined gravimetrically during cropping season.

The pre-defined level of MAD was calculated by the following equation (Martin et al., 1990):

$$
\text { Depletion }(\%)=100 \times \frac{1}{n} \sum^{n}\left(\frac{F C i-\theta i}{F C i-W P}\right)
$$

Where, $n$ is the number of sub-divisions of the effective rooting depth used in the soil moisture sampling, $\mathrm{FC}_{i}$ the soil moisture at field capacity for $i$ th layer, $\theta_{i}$ the soil moisture in $i$ th layer and WP the soil moisture at permanent wilting point.

The amount of water applied after the attainment of pre-defined MAD (\%) was calculated as

$$
\mathbf{v} d=\frac{\text { MAD }(\mathbf{F C}-\mathbf{W P}) \mathbf{R} z \times \mathbf{A}}{100}
$$

Where, $V_{\mathrm{d}}$ the volume of irrigation water applied, $\mathrm{R}_{Z}$ the effective rooting depth and $A$ the surface area of the plot.

The irrigation interval and quantity of water applied during each irrigation events increased from $\mathrm{I}_{1}$ to $\mathrm{I}_{3}$ and $\mathrm{I}_{4}$ given four irrigations critical growth stages. The plants were raised throughout the period from sowing to maturity according to recommended agronomic practices for wheat under irrigated condition. The crop was harvested manually at the physiological maturity. Crop yield was recorded as per the established procedure for each treatment. Daily meteorological data for the crop growing period were obtained from the Agrometeorological observatory, located approx. $2.0 \mathrm{~km}$ from the experimental plot.

Milling tests: After threshing, random samples were taken from each treatment to evaluate grain quality. Wheat whole flour was obtained by milling grain samples using a Cyclotec 1093 sample mill (Foss, Tecator, Sweden). Percentage of flour recovery, coarse and fine bran were measured after grain milling by Quadrumat Senior mill (Brabender, Germany), which was operated for milling of $250 \mathrm{~g}$ grain sample to obtain flour (Method AACC 26-21A). The weight of flour and bran was taken separately and flour recovery percentage was calculated using the formula:

$$
\text { Flour recovery percentage }=\frac{\mathrm{A}}{\mathrm{A}+\mathrm{B}} \quad \mathrm{X} 100
$$

Where, $\mathrm{A}=$ Weight of flour

$$
\mathrm{B}=\text { Weight of bran }
$$

The hectolitre weight was determined by taking wheat grains sample in $100 \mathrm{ml}$ measuring cylinder, weighed and expressed as $\mathrm{kg} \mathrm{hl}^{-1}$ (AACC, 1983). Grain hardness and diameter were measured by Single Kernel Characterization system (SKCS) 4100 (from Perten Instruments, Australia). Water absorption of dough was estimated by using Brabender Farinograph (AACC 54-21.01). Water absorption was estimated as the percentage of water in the dough for reaching strength of $500 \mathrm{BU}$.

Technological tests: The protein content in the grain samples were determined by Kjeldahl method using the Autokjeltech system 3100 (Foss, Tecator, USA). 
Wet gluten content was determined by hand-washing method (AACC 38-10.01). Dry gluten was obtained after oven drying of the wet gluten sample (dough) at $105{ }^{\circ} \mathrm{C}$ for 6 hours. The sedimentation test was determined by sodium dodecyl sulphate (SDS) method as suggested by Axford et al. (1979). The grain quality analyses were carried out at Grain Quality Laboratory, IARI, New Delhi.

Statistical analysis: The data collected from laboratory were compiled and properly tabulated. These were subjected to statistical analysis by using 'Analysis of Variance Technique' as suggested by Gomez and Gomez (1983). Standard errors of mean and critical difference (CD) values at 5\% level of probability were computed for making comparison between treatments.

\section{RESULTS AND DISCUSSION}

Weather growing conditions during the crop period: Daily air temperature, pan evaporation, relative humidity, sunshine hours and rainfall during the period of study are shown in Fig. 1. Data revealed that cropping season 2011-12 appeared relatively warmer during vegetative stage. Temperature (Tmax and $T \mathrm{~min}$ ) during reproductive stage follow same trend in both cropping years except heading to anthesis growth stage in November 1 and November 16 sowing, when Tmax and Tmin were found higher in 201011. The November 1 sowing experienced temperature in the ranges of 9.5- 24.1 ${ }^{\circ} \mathrm{C}$ and 6.9- $20.9{ }^{\circ} \mathrm{C}$, while December 16 sowing in the range of $6.3-20.3{ }^{\circ} \mathrm{C}$ and $13.5-31.1^{\circ} \mathrm{C}$ during vegetative and reproductive stages of wheat, respectively. During reproductive stage, relatively lower temperature was noticed in November sowings and relatively higher temperature in December sowings. The different sowing dates selected in this study resulted in exposure of plants to varied temperatures events during reproductive period. The overall atmospheric evaporative demand was highest in 2011-12, ranges from 4.2 to $6.9 \mathrm{~mm} \mathrm{day}^{-1}$. The higher atmospheric evaporative demand ( $\left.>4 \mathrm{~mm} \mathrm{day}^{-1}\right)$ was observed during reproductive stage but it was 2.9 $\mathrm{mm} \mathrm{day}^{-1}$ during February 2011. The average daily bright sunshine during crop growth periods were 5.5 and $5.2 \mathrm{~h}$ for 2010-11 and 2011-12, respectively. In 2011-12, rainfall was approximately lower than that in 2010-11. Total rainfall received by crop from sowing to maturity was $63.5 \mathrm{~mm}$ in $2010-11$ higher than 40.8 $\mathrm{mm}$ in 2011-12 cropping season. There was a good

Table 1. Effect of sowing dates and irrigation regimes on milling properties of wheat grain.

\begin{tabular}{|c|c|c|c|c|c|c|}
\hline Year & & $\begin{array}{l}\text { Hectolitre weight } \\
\left(\mathrm{kg} \mathrm{hl}^{-1}\right)\end{array}$ & $\begin{array}{l}\text { Grain hardness } \\
(\%)\end{array}$ & $\begin{array}{l}\text { Grain diameter } \\
(\mathrm{mm})\end{array}$ & $\begin{array}{l}\text { Flour recovery } \\
\text { (\%) }\end{array}$ & $\begin{array}{l}\text { Water absorption } \\
\text { of flour }(\%)\end{array}$ \\
\hline \multirow{14}{*}{$\begin{array}{l}(\text { Year I) } \\
2010-11\end{array}$} & \multicolumn{6}{|c|}{ Sowing date } \\
\hline & $\mathrm{S}_{1}$ & 80.24 & 85.83 & 2.87 & 68.23 & 56.23 \\
\hline & $\mathrm{S}_{2}$ & 79.66 & 83.51 & 2.83 & 68.06 & 56.18 \\
\hline & $\mathrm{S}_{3}$ & 79.31 & 81.17 & 2.79 & 67.26 & 55.90 \\
\hline & $\mathrm{S}_{4}$ & 78.28 & 74.66 & 2.77 & 66.55 & 55.72 \\
\hline & $\mathrm{Sem}+$ & 0.20 & 0.75 & 0.01 & 0.08 & 0.13 \\
\hline & $\begin{array}{l}\text { C.D. } \\
(\mathrm{P}=0.05)\end{array}$ & 0.70 & 2.62 & 0.05 & 0.30 & 0.48 \\
\hline & \multicolumn{6}{|c|}{ Irrigation regime } \\
\hline & $\mathrm{I}_{1}$ & 79.89 & 80.21 & 2.85 & 68.03 & 56.21 \\
\hline & $\mathrm{I}_{2}$ & 79.54 & 80.35 & 2.83 & 67.86 & 56.06 \\
\hline & $\mathrm{I}_{3}$ & 79.00 & 83.26 & 2.78 & 66.91 & 55.68 \\
\hline & $\mathrm{I}_{4}$ & 79.05 & 81.35 & 2.80 & 67.29 & 56.08 \\
\hline & Sem \pm & 0.23 & 0.87 & 0.02 & 0.10 & 0.06 \\
\hline & $\begin{array}{l}\text { C.D. } \\
(P=0.05)\end{array}$ & 0.86 & 3.26 & 0.08 & 0.40 & 0.25 \\
\hline \multirow{14}{*}{$\begin{array}{l}\text { (Year II) } \\
2011-12\end{array}$} & \multicolumn{6}{|c|}{ Sowing date } \\
\hline & $\mathrm{S}_{1}$ & 81.40 & 73.83 & 2.90 & 63.16 & 62.03 \\
\hline & $\mathrm{S}_{2}$ & 81.05 & 73.08 & 2.88 & 62.45 & 62.00 \\
\hline & $\mathrm{S}_{3}$ & 80.51 & 72.08 & 2.86 & 61.76 & 62.00 \\
\hline & $\mathrm{S}_{4}$ & 79.44 & 66.83 & 2.81 & 61.55 & 61.92 \\
\hline & $\operatorname{Sem} \pm$ & 0.33 & 1.38 & 0.04 & 0.22 & 0.08 \\
\hline & $\begin{array}{l}\text { C.D. } \\
(P=0.05)\end{array}$ & 1.15 & 4.76 & 0.14 & 0.78 & 0.29 \\
\hline & \multicolumn{6}{|c|}{ Irrigation regime } \\
\hline & $\mathrm{I}_{1}$ & 81.47 & 70.58 & 2.89 & 62.84 & 62.13 \\
\hline & $\mathrm{I}_{2}$ & 80.53 & 70.92 & 2.88 & 62.41 & 62.10 \\
\hline & $\mathrm{I}_{3}$ & 79.95 & 72.25 & 2.83 & 61.74 & 61.76 \\
\hline & $\mathrm{I}_{4}$ & 80.44 & 72.08 & 2.84 & 61.94 & 62.00 \\
\hline & $\operatorname{Sem} \pm$ & 0.23 & 0.81 & 0.03 & 0.21 & 0.09 \\
\hline & $\begin{array}{l}\text { C.D. } \\
(\mathrm{P}=0.05)\end{array}$ & 0.87 & 3.03 & 0.11 & 0.82 & 0.36 \\
\hline
\end{tabular}


Table 2. Effect of sowing dates and irrigation regimes on technological properties of wheat grain.

\begin{tabular}{|c|c|c|c|c|c|c|c|}
\hline Year & & $\begin{array}{l}\text { Protein content } \\
(\%)\end{array}$ & $\begin{array}{l}\text { Wet gluten } \\
\text { content }(\%)\end{array}$ & $\begin{array}{l}\text { Dry gluten } \\
\text { content }(\%)\end{array}$ & $\begin{array}{l}\text { Sedimentation } \\
\text { value }(\mathrm{ml})\end{array}$ & $\begin{array}{l}\text { Coarse } \\
\text { bran }(\%)\end{array}$ & $\begin{array}{l}\text { Fine } \\
\text { bran (\%) }\end{array}$ \\
\hline \multirow{14}{*}{$\begin{array}{l}(\text { Year I) } \\
2011\end{array}$} & \multicolumn{7}{|c|}{ Sowing date } \\
\hline & $\mathrm{S}_{1}$ & 11.94 & 25.03 & 9.58 & 30.50 & 28.55 & 3.22 \\
\hline & $\mathrm{S}_{2}$ & 12.18 & 25.59 & 9.97 & 31.67 & 29.18 & 2.76 \\
\hline & $\mathrm{S}_{3}$ & 12.52 & 26.32 & 10.33 & 32.08 & 30.02 & 2.72 \\
\hline & $\mathrm{S}_{4}$ & 12.56 & 28.92 & 11.12 & 32.08 & 30.52 & 2.93 \\
\hline & $\mathrm{S}_{1}$ & 0.09 & 0.50 & 0.26 & 0.15 & 0.06 & 0.05 \\
\hline & $\begin{array}{l}\text { C.D. } \\
(\mathrm{P}=0.05)\end{array}$ & 0.34 & 1.74 & 0.90 & 0.55 & 0.22 & 0.18 \\
\hline & \multicolumn{7}{|c|}{ Irrigation regime } \\
\hline & $\mathrm{I}_{1}$ & 12.05 & 24.61 & 10.04 & 31.08 & 29.04 & 2.93 \\
\hline & $\mathrm{I}_{2}$ & 12.30 & 27.01 & 10.23 & 31.17 & 29.19 & 2.95 \\
\hline & $\mathrm{I}_{3}$ & 12.45 & 27.22 & 10.61 & 32.08 & 30.37 & 2.72 \\
\hline & $\mathrm{I}_{4}$ & 12.40 & 27.01 & 10.12 & 32.00 & 29.66 & 3.05 \\
\hline & $\operatorname{Sem} \pm$ & 0.10 & 0.67 & 0.20 & 0.25 & 0.10 & 0.08 \\
\hline & $\begin{array}{l}\text { C.D. } \\
(\mathrm{P}=0.05)\end{array}$ & 0.37 & 2.51 & 0.76 & 0.93 & 0.38 & 0.32 \\
\hline \multirow{14}{*}{$\begin{array}{l}\text { (Year II) } \\
2012\end{array}$} & \multicolumn{7}{|c|}{ Sowing date } \\
\hline & $\mathrm{S}_{1}$ & 12.77 & 31.69 & 11.11 & 33.75 & 34.45 & 2.39 \\
\hline & $\mathrm{S}_{2}$ & 13.05 & 32.74 & 11.38 & 34.67 & 35.04 & 2.51 \\
\hline & $\mathrm{S}_{3}$ & 13.34 & 33.24 & 11.61 & 34.75 & 35.75 & 2.49 \\
\hline & $\mathrm{S}_{4}$ & 13.78 & 33.26 & 11.90 & 35.00 & 35.86 & 2.59 \\
\hline & $\operatorname{Sem} \pm$ & 0.09 & 1.58 & 0.11 & 0.50 & 0.20 & 0.06 \\
\hline & $\begin{array}{l}\text { C.D. } \\
(\mathrm{P}=0.05)\end{array}$ & 0.32 & 5.47 & 0.38 & 1.73 & 0.72 & 0.23 \\
\hline & \multicolumn{7}{|c|}{ Irrigation regime } \\
\hline & $\mathrm{I}_{1}$ & 13.03 & 31.48 & 11.08 & 33.67 & 34.74 & 2.42 \\
\hline & $\mathrm{I}_{2}$ & 13.24 & 31.96 & 11.53 & 34.42 & 35.01 & 2.58 \\
\hline & $\mathrm{I}_{3}$ & 13.36 & 34.06 & 11.79 & 35.33 & 36.02 & 2.24 \\
\hline & $\mathrm{I}_{4}$ & 13.32 & 33.42 & 11.60 & 34.75 & 35.33 & 2.73 \\
\hline & $\operatorname{Sem} \pm$ & 0.14 & 1.64 & 0.22 & 0.38 & 0.23 & 0.04 \\
\hline & $\begin{array}{l}\text { C.D. } \\
(P=0.05)\end{array}$ & 0.52 & 6.12 & 0.84 & 1.44 & 0.84 & 0.16 \\
\hline
\end{tabular}

amount of rainfall in February $(49.9 \mathrm{~mm})$ in first year and January $(14.8 \mathrm{~mm})$ and March $(19.2 \mathrm{~mm})$ during second year of experimentation. The average relative humidity was 64 and $60 \%$ in respective years and the sky was cloud free for most of the time during crop growth period.

\section{Milling characteristics}

Hectolitre weight: The hectolitre weight (HW) was significantly affected by sowing dates and irrigation regimes (Table 1). In both seasons, HW varied between 78 and $81 \mathrm{~kg} \mathrm{hl}^{-1}$ among sowing dates. The significantly highest HW (80.2 and $81.4 \mathrm{~kg} \mathrm{hl}^{-1}$ in the first and second season, respectively) was observed in $\mathrm{S}_{1}$, which was at par with $\mathrm{S}_{2}$ and lowest in $\mathrm{S}_{4}$ (78.3 and $\left.79.4 \mathrm{~kg} \mathrm{hl}^{-1}\right)$. Among irrigation regimes, the highest HW (79.9 and $81.5 \mathrm{~kg} \mathrm{hl}^{-1}$ ) was found in $\mathrm{I}_{1}$ and lowest (79.0 and $79.9 \mathrm{~kg} \mathrm{hl}^{-1}$ ) was obtained in $\mathrm{I}_{3}$ irrigation regime. The highest $\mathrm{HW}$ in $\mathrm{S}_{1}$ might have occurred due to favourable prevailing temperature conditions. The decline in HW might be due to high temperature in $S_{3}$ and $S_{4}$ sowing and thus subjecting to forced maturity and drying of immature seeds at the time of grain filling, led to reduction in grain size and poor density and thereby lower HW. Kaur et al. (2010) found that
HW decreased from $75.7 \mathrm{~kg} \mathrm{~h}^{-1}$ in 15 th November sowing to $73.1 \mathrm{~kg} \mathrm{hl}^{-1}$ in 25 th December sowing. Similarly, significantly decline in HW was observed due to delayed sowing in previous studies (Tyagi et al., 2003; Asseng et al., 2004). The HW decrease with increase in soil moisture depletion and recorded lowest in $\mathrm{I}_{3}$ irrigation regime. Moisture stress during grain filling reduces $\mathrm{HW}$ as compared to treatments receiving frequent irrigation $\left(I_{1}\right.$ and $\left.I_{2}\right)$. The probable reason for this is that the photosynthates deposited in grain are known to come from remobilization of assimilates deposited in other plant organs and photosynthesis of the flag leaf, stem and ear. The frequently irrigated treatments enabled the crop to accumulate sufficient carbohydrate reserve in leaf area to sufficiently provide source assimilates for grain filling as compared to less frequently irrigated regimes.

Grain hardness: Grain hardness (GH) was significantly affected by sowing dates in both seasons (Table 1 ). The GH outcome was $\geq 75$ and $<75$ in $2010-11$ and 2011-12, respectively irrespective of sowing dates and irrigation regimes. The highest $\mathrm{GH}$ outcome was observed in $\mathrm{S}_{1}(85.8$ and $73.8 \%)$ and lowest in $\mathrm{S}_{4}(74.7$ and $66.8 \%$ ). The effect of irrigation regime on $\mathrm{GH}$ was 

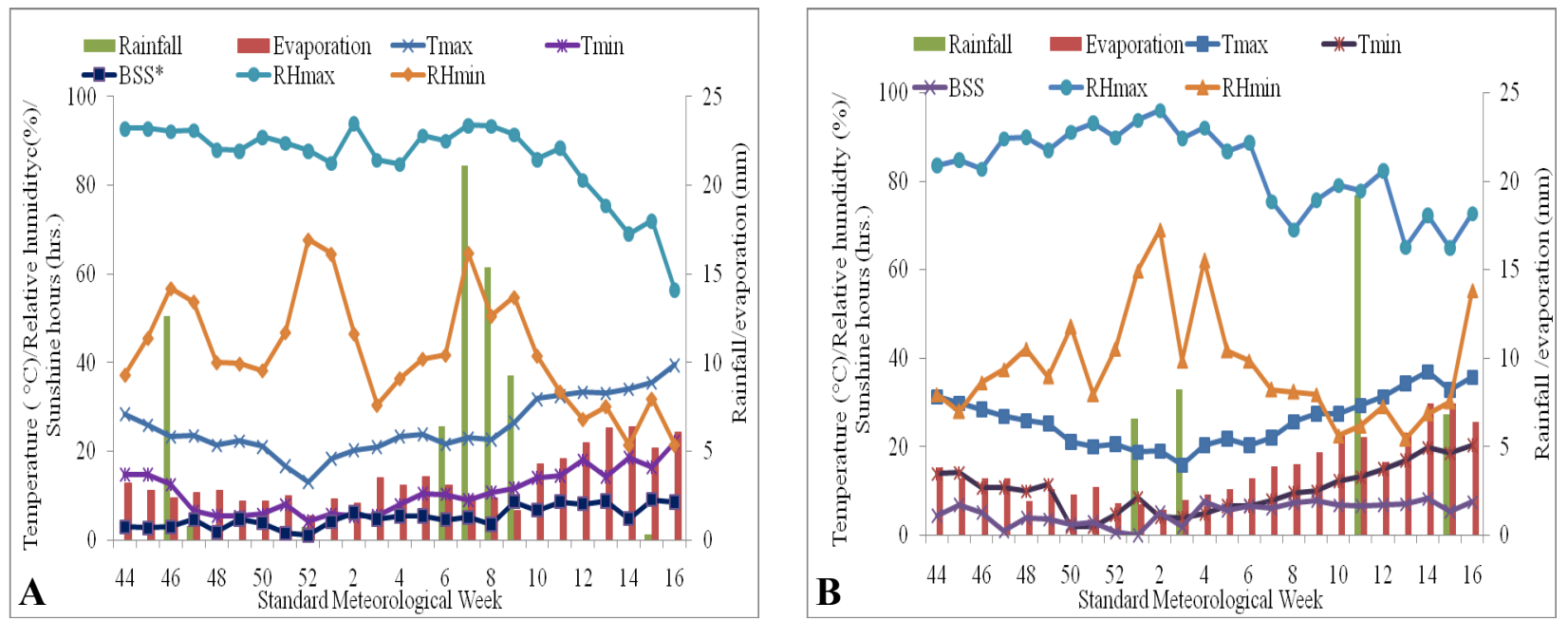

Fig. 1. Weather conditions during cropping season 2010-11 (a) and 2011-12 (b).

non-significant (Table 1). The highest GH was recorded in $\mathrm{I}_{3}(83.3$ and $72.3 \%$ ) having less frequent irrigation and lowest in $I_{1}(80.2$ and 70.6) irrigation regime in both seasons. GH outcome $>75$ is desired quality characteristics (Das et al., 2006; Ram and Mishra, 2008). GH outcome $>75$ in 2010-11 was because of relatively cooler growing season. Such results were also obtained by Coventry et al. $(2011 \mathrm{a}, \mathrm{b})$.

Grain diameter: The effect of sowing dates on grain diameter (GD) was found significant in 2010-11 and non-significant in 2011-12 (Table 1). The highest GD ( 2.87 and $2.90 \mathrm{~mm}$ ) was observed in $\mathrm{S}_{1}$ followed by $\mathrm{S}_{2}, \mathrm{~S}_{3}$ and lowest $(2.77$ and $2.81 \mathrm{~mm})$ in $\mathrm{S}_{4}$. The per cent increase was 3.6 and 3.2 in GD in $\mathrm{S}_{1}$ over $\mathrm{S}_{4}$ in 2010-11 and 2011-12, respectively. In both seasons, effect of irrigation regimes on GD was non-significant (Table 1). However, the highest GD (2.85 and 2.89 $\mathrm{mm}$ ) was recorded in $\mathrm{I}_{1}$ irrigation regime but was at par with $\mathrm{I}_{2}$ and lowest $(2.78$ and $2.83 \mathrm{~mm})$ in $\mathrm{I}_{3}$ irrigation regime. There was an increase in GD by 1.8 and $1.7 \%$ in $I_{1}$ over $I_{3}$ in the first and second season, respectively. The lowest grain diameter (GD) in $\mathrm{S}_{4}$ was because of reduced grain size associated with high temperature. The GD is affected by temperature and moisture stress during reproductive stage. Moisture stress might have terminated cell expansion, grain growth and affecting grain size through reduction in carbohydrate accumulation. These findings corroborate with earlier findings (Panazzo and Eagles, 2000; Waraich et al., 2010; Coventry et al., 2011b).

Flour recovery percentage: The flour recovery was significantly affected by different sowing dates and irrigation regimes (Table 1). The highest percentage of flour recovery (68.2 and 63.2\%) was obtained in $S_{1}$ while lowest percentage of flour recovery (66.6 and $61.6 \%$ ) recorded in $\mathrm{S}_{4}$. Amongst irrigation regimes, the highest percentage of flour recovery (68.0 and 62.8\%) was obtained in $I_{1}$ irrigation regime having more frequent irrigation, followed by $\mathrm{I}_{2}, \mathrm{I}_{4}$ and lowest in $\mathrm{I}_{3}$ irrigation regime having lowest frequency of irrigation.
The highest percentage of flour recovery in $S_{1}$ may be due to the increase in grain weight and size. The low values of flour recovery and higher percentage of coarse bran are associated with poorly filled, immature and shriveled grain that may yield less flour than sound grain. Similar results were also reported earlier (Seleiman et al., 2011a). Frequent irrigation with small quantity as in $I_{1}$ led to a significant increase in flour recovery and decrease in coarse bran percentage. Variation in flour yield directly relates to differences in the proportion of endosperm in the kernel (Bergman et al., 1998), which is influenced by grain weight and size as it is expected to be bold and non-shriveled grain in $I_{1}$. Such results were reported in previous studies (Zhou et al., 2003; Zhang et al., 2005; Seleiman et al., 2011b).

Water absorption of flour: The effect of sowing date and irrigation regimes on water absorption is shown in Table 1 . The highest water absorption was observed in $\mathrm{S}_{1}(56.2$ and $62.0 \%)$, which is at par with $\mathrm{S}_{2}$ and lowest was observed in $\mathrm{S}_{4}$. Irrigation had significant effect on water absorption of flour in 2010-11. The highest water absorption was observed in $\mathrm{I}_{1}$ (56.2 and 62.1\%) irrigation regime and lowest in $\mathrm{I}_{3}(55.7$ and $61.8 \%)$ in both seasons.

\section{Technological characteristics}

Grain protein content: Sowing dates had significant effect on grain protein content (PC) as given in Table 2 . The delayed sowing progressively and significantly increased the PC. The highest PC (12.6 and 13.8\%) was recorded in $\mathrm{S}_{4}$, followed by $\mathrm{S}_{3}$ and lowest (11.9 and $12.8 \%$ ) in the $S_{1}$, but was at par with $S_{2}$. The increase in PC varied between 5.2- 7.9\% in $\mathrm{S}_{4}$ over $\mathrm{S}_{1}$ sowing. The effect of irrigation was significant in first season and non-significant in second season. The highest PC (12.5 and 13.4\%) was obtained in $\mathrm{I}_{3}$ and lowest (12.1 and $13.0 \%$ ) in $I_{1}$ irrigation regime in both the seasons. Sowing had a large effect on PC and this was probably starch deposition driven by the thermal condition prevailing during grain filling stage. This was 
particularly evident on comparing the $\mathrm{S}_{1}$ and $\mathrm{S}_{4}$ sowing. The variation in $\mathrm{PC}$ can also be explained by dilution effect. The increase in PC with increased temperature and delayed sowing is consistent with previous studies (Gooding et al., 2003; Zende et al., 2005, Motzo et al., 2007; Farooq et al., 2011; Singh et al., 2012). The highest $P C$ in $I_{3}$ irrigation regime might be due to moisture stress has incremental effect on nitrogen accumulation per unit starch and reduction in the carbohydrates synthesis. On other hand, adequate moisture in $\mathrm{I}_{1}$ and $\mathrm{I}_{2}$ may decrease $\mathrm{PC}$ by dilution of nitrogen with carbohydrates accumulation. Our observation that the decrease in PC with increase in irrigation frequencies or soil moisture content is consistent findings of other studies (Guttieri et al., 2005; Waraich et al., 2010; Coventry et al., 2011b; Singh et al., 2012; Ram et al., 2013).

Wet and dry gluten content: The delay in sowing progressively increased wet gluten content (WGC) of wheat grains (Table 2). The highest WGC was found in $\mathrm{S}_{4}$ and lowest in $\mathrm{S}_{1}$ sowing. The WGC in $\mathrm{S}_{1}$ and $\mathrm{S}_{2}$ sowing was at par with each other. The highest WGC recorded in $\mathrm{I}_{3}$ and lowest in $\mathrm{I}_{1}$ irrigation regime in both the seasons. Delay in sowing had progressively increased dry gluten content (DGC) of wheat grains (Table 2). The highest DGC (11.1 and 11.9\%) was recorded in $\mathrm{S}_{4}$ and lowest (9.6 and 11.1\%) in $\mathrm{S}_{1}$ in both seasons. The DGC in $S_{1}$ and $S_{2}$ sowing was found at par with each other in both seasons. The DGC increased by 16.5 and $7.1 \%$ in $\mathrm{S}_{4}$ over $\mathrm{S}_{1}$ sowing in 2010 -11 and 2011-12, respectively. Among irrigation regimes, the highest DGC (10.6 and $11.8 \%)$ recorded in $\mathrm{I}_{3}$ and lowest $(10.0$ and $11.1 \%)$ in $\mathrm{I}_{1}$ irrigation regime. The DGC in $\mathrm{I}_{2}$ found almost similar with $\mathrm{I}_{4}$ irrigation regime. The increase in DGC varied between 5.7$6.4 \%$ in $I_{3}$ over $I_{1}$ irrigation regime. The wet and dry gluten content in wheat grain increased significantly with each successive delay in sowing from $S_{1}$ to $S_{4}$. The significant increase in dry gluten content can be explained by the dilution effect. The gluten content is also associated with the PC. This fact can further be verified from the significantly lower $\mathrm{PC}$ in $\mathrm{S}_{1}$ and $\mathrm{S}_{2}$. The percentage of dry gluten content was in the range of $0.8-1.7 \%$ and $5.6-6.4 \%$ in $\mathrm{I}_{3}$ irrigation regime over $\mathrm{I}_{1}$ in first and second season, respectively.

Sedimentation value: The effect of sowing dates and irrigation regimes on sedimentation value is given in Table 2. The effect of sowing dates on sedimentation value was significant in 2010-11 and non-significant in 2011-12. The highest sedimentation value (32.1 and 35 $\mathrm{ml}$ ) was found in $\mathrm{S}_{4}$, which was at par with $\mathrm{S}_{3}$. The lowest sedimentation value $(30.5$ and $33.8 \mathrm{ml})$ was recorded in the $\mathrm{S}_{1}$ in both seasons. The delay in sowing led to increase in sedimentation value in both seasons. Irrigation effects were significant on sedimentation value. The highest sedimentation value was observed in $\mathrm{I}_{3}(32.08$ and $35.3 \mathrm{ml})$ and lowest $(31.1$ and $33.8 \mathrm{ml})$ in $I_{1}$ irrigation regime. Sedimentation value of flour increased with increasing temperature as sowing de- layed. Moisture stress significantly increased sedimentation value in $\mathrm{I}_{3}$ and $\mathrm{I}_{4}$ irrigation regime.

Coarse bran: Data in Table 2 revealed effect of sowing dates and irrigation regimes on coarse bran of wheat grain. The significantly highest values of coarse bran obtained in $\mathrm{S}_{4}\left(30.5\right.$ and $35.9 \%$ ) over lowest in $\mathrm{S}_{1}$ (28.6 and 34.5\%). Among irrigation regimes, significantly highest percentage of coarse bran was obtained in $\mathrm{I}_{3}(30.4$ and $36.0 \%)$ and lowest (29.0 and 34.7\%) in $\mathrm{I}_{1}$ irrigation regime.

Fine bran: Effect of sowing date and irrigation regimes on fine bran of wheat grain is shown in Table 2 . The significantly highest values of fine bran obtained in $\mathrm{S}_{1}(3.2 \%)$ over lowest in $\mathrm{S}_{3}(2.7 \%)$ in first season. The difference between sowing dates were nonsignificant in second season. The significantly highest percentage of fine bran was obtained in $\mathrm{I}_{4}$ (3.1 and $2.7 \%$ ) and lowest (2.7 and $2.2 \%)$ in $\mathrm{I}_{3}$ irrigation regime.

\section{Conclusion}

Study revealed that the November 1 and November 16 sowing, although resulting in lower protein content (11.9-13.2\%) but maintains higher grain hardness (73.1-85.8), flour recovery $(62.5-68.2 \%)$ and hectolitre weight (79.7-80.2 $\mathrm{kg} \mathrm{hl}^{-1}$ ) than other sowing dates. Irrigation scheduling at $25 \%$ MAD of ASW and $50 \%$ MAD of ASM yields optimum protein content (12.113.2), higher flour recovery $(62.2-68.2 \%)$ and lower percentage of coarse bran (28.6-35.0\%). The effect of irrigation regimes was non-significant on grain hardness, grain diameter and dry gluten content. Therefore, it may be inferred that optimum milling and technological properties of wheat grain can be maintained by sowing till mid-November and irrigation scheduling up to $50 \%$ depletion of ASM in sandy loam soils of semiarid region.

\section{REFERENCES}

AACC (1983). Approved Methods of the American Association of Cereal Chemists, Vol. 8. St. Paul, Minnesota, USA.

Asseng, S., Jameison, P.D., Kimball, B., Pinter, P., Sayre, K., Bowden, J.W. and Howden, S.M. (2004). Simulated wheat growth affected by rising temperature increased water deficit and elevated atmospheric $\mathrm{Co}_{2}$. Field Crops Res., 85: 85-102.

Axford, D.W.E., McDermott, E.E. and Redman, D.G. (1979). Note on the sodium dodecyl sulphate test of bread making quality: Comparison with Pelshenke and Zeleny tests. Cereal Chem., 56: 582-584.

Bergman, C.J., Gualberto, D.G., Cambell, K.G., Sorrels, M.E. and Finney, I. (1998). Genotype and environment effects on wheat quality traits in a population derived from a soft by hard cross. Cereal Chem., 75: 729-737.

Coventry, D.R., Gupta, R.K., Yadav, A., Poswal, R.S., Chhokar, R.S., Sharma, R.K., Yadav, V.K., Gill, S.C., Kumar, A., Mehta, A., Kleemann, S.G.L., Bonamano, A. and Cummins, J.A. (2011a). Wheat quality and productivity as affected by varieties and sowing time in Haryana, India. Field Crops Res., 123: 214-225. 
Coventry, D.R., Yadav, A., Poswal, R.S., Sharma, R.K., Gupta, R.K., Chhokar, R.S., Gill, S.C., Kumar, V., Kumar, A., Mehta, A., Kleemann, S.G.L. and Cummins, J.A. (2011b). Irrigation and nitrogen scheduling as a requirement for optimising wheat yield and quality in Haryana, India. Field Crops Res., 123: 80-88.

Das, B.K., Alka, S., Marathe, S.A., Rao, V.S. and Bhagwat, S.G. (2006). Evaluation of bread and chapatti making quality of wheat selections and parents differing in HMW subunits of glutenin. J. Food Sci. Technol., 43: 69-72.

Farooq, M., Bramley, H., Palta, J.A. and Siddique, K.H.M. (2011). Heat stress in wheat during reproductive and grain filling phases. Crit. Rev. Plant Sci., 30: 491-507.

Gomez, K.A. and Gomez, A.A. (1983). Statistical procedures for agricultural research. John Wiley and Sons, Inc. London, UK.

Gooding, M.J., Ellis, R.H., Shewry, P.R. and Schofield, J.D. (2003). Effects of restricted water availability and increased temperature on the grain filling, drying and quality of winter wheat. J. Cereal Sci., 37: 295-309.

Guttieri, M.J., McLean, R., Stark, J.C. and Souza, E. (2005). Managing irrigation and nitrogen fertility of hard spring wheats for optimum bread and noodle quality. Crop Sci., 45: 2049-2059.

Kaur, A., Pannu, R.K. and Buttar, G.S. (2010). Quality of wheat (T. aestivum) as influenced by sowing dates and nitrogen scheduling. Indian J. Agric. Sci., 80: 781-785.

Martin, D.L., Stegman, E.C. and Freres, E. (1990). Irrigation scheduling principles. In: Hoffman, G.L., Howell, T.A., Solomon, K.H. (Eds.), Management of Farm Irrigation Systems. ASAE Monograph, pp. 155-372.

Motzo, R. Fois, S. and Giunta, F. (2007). Protein content and gluten quality of durum wheat as affected sowing date. J. Sci. food Agric., 87: 1480-1488.

Panazzo J.F. and Eagles H.A. (2000). Cultivar and environmental effects on quality characters in wheat. II. Protein. Aust. J. Agric. Res., 51: 629-36.

Ram, H., Dadhwal, V., Vashist, K.K. and Kaur, H. (2013).
Grain yield and water use efficiency of wheat (Triticum aestivum L.) in relation to irrigation levels and rice straw mulching in North West India. Agric. Water Manag, 128; 92-101.

Ram, S. and Mishra, B. (2008). Review: biochemical basis and molecular genetics of processing and nutritional quality of wheat. J. Plant Biochem. Biotechnol., 17: 111-126.

Seleiman, M., Ibrahim, M., Abdel-Aal, S. and Zahran, G. (2011a). Effect of sowing dates on productivity, technological and rheological characteristics of breat wheat. $J$. Agro Crop Sci., 2: 1-6.

Seleiman, M., Ibrahim, M., Abdel-Aal, S. and Zahran, G. (2011b). Productivity, grain and dough quality of bread wheat grown with different water regimes. J. Acro Crop Sci., 2: 11-17.

Singh, S., Gupta, A.K. and Kaur, N. (2012). Influence of drought and sowing time on protein composition, antinutrients, and mineral contents of wheat. Sci. World J., doi: 10.1100/2012/485751.

Singh, S., Gupta, A.K., Gupta, S.K. and Kaur, N. (2010). Effect of sowing time on protein quality and starch pasting characteristics in wheat (Triticum aestivum L.) genotypes grown under irrigated and rainfed conditions. Food Chem., 122: 559-565.

Tyagi, P.K., Pannu, R.K., Sharma, K.D., Chaudhary, B.D. and Singh, D.P. (2003). Response of different cultivars to terminal heat stress. T. Agrochem. Culti., 24: 20 21.

Waraich, E.A., Ahmad, R., Saifullah, S.A. and Ahmad, A. (2010). Impact of water and nutrient management on nutritional quality of wheat. Plant Nutr., 33: 640-653.

Zende, N.B., Sethi, H.N., Karunakar, A.P. and Jiotode, D.J. (2005). Effect of sowing time and fertility levels on yield and quality of durum wheat genotypes. Res. Crops, 6: 194-196.

Zhang, Y., Quail, K., Mugford, D.C. and He, Z.H. (2005). Milling quality and white salt noodle color of Chinese wheat cultivars. Cereal Chem., 82: 633-638. 